\title{
Verification of the Mechanism of Glyphosate Resistance in ITALIAN RYEGRASS BIOTYPES ${ }^{1}$
}

\author{
Verificação do Mecanismo de Resistência ao Glyphosate em Biótipos de Azevém
}

\author{
VARGAS, L. ${ }^{2}$, RUCHEL, Q. ${ }^{3}$, AGOSTINETTO, D. ${ }^{3}$, LAMEGO, F.P. ${ }^{4}$, LANGARO, A.C. ${ }^{5}$, and \\ PIESANTI, S.R. ${ }^{3}$
}

\begin{abstract}
The intense use of glyphosate for weed control led to the emergence of several cases of resistance to this herbicide. Weeds can survive the application of herbicides due to several factors, which may or may not be related to the herbicide site of action. The objectives of this study were to quantify the accumulation of shikimate in ryegrass biotypes in response to glyphosate application; investigate possible mutations on the EPSPs gene in susceptible and resistant biotypes; and evaluate the response of ryegrass biotypes to the application of glyphosate after treatment with a metabolism inhibitor of cyt P450 monooxygenase. The seeds of ryegrass biotypes with suspected resistance came from the municipality of São Valentim, RS (SVA 1 and SVA 4) and Passo Fundo, RS (PFU 5) and the seeds of the susceptible biotype (SVA 2), from São Valentim. The results demonstrated that, SVA biotype 2 accumulated more shikimate than any of the resistant biotypes, regardless of the herbicide dose used. The EPSPs gene showed no point mutation previously associated with the resistance to glyphosate, and the evaluated biotypes show no metabolism of glyphosate by the cyt P450 complex concerning inhibition by piperonyl butoxide (PBO) and malathion.
\end{abstract}

Keywords: shikimic acid, EPSPs, Lolium multiflorum, metabolism.

\begin{abstract}
RESUMO - A intensa utilização do glyphosate para controle de plantas daninhas levou ao surgimento de vários casos de resistência a esse herbicida. As plantas daninhas podem sobreviver à aplicação de herbicidas devido a diversos fatores, os quais podem estar relacionados ou não ao local de ação do herbicida. Assim, os objetivos deste trabalho foram quantificar o acúmulo de chiquimato em biótipos de azevém, em resposta a aplicação de glyphosate; investigar possiveis mutações no gene da EPSPs em biótipos suscetiveis e resistentes; e avaliar a resposta de biótipos de azevém à aplicação de glyphosate, após tratamento com inibidor de metabolismo da cyt-P450 mono-oxigenase. As sementes dos biótipos de azevém suspeitos de resistência provieram do município de São Valentin, RS (SVA 1 e SVA 4), e Passo Fundo, RS (PFU 5), e as do biótipo suscetivel (SVA 2), de São Valentin. Os resultados demonstram que o biótipo SVA 2 acumulou mais chiquimato que os biótipos resistentes, independentemente da dose do herbicida. O gene da EPSPs não apresentou mutação pontual previamente associada com a resistência ao glyphosate nos biótipos avaliados, os quais não apresentaram metabolismo do glyphosate pelo complexo cyt-P450 no que se refere à inibição por malathion e butóxido de piperonila (PBO).
\end{abstract}

Palavras-chave: ácido chiquímico, EPSPs, Lolium multiflorum, metabolização.

\section{INTRODUCTION}

Ryegrass (Lolium multiflorum) is an annual-cycle winter Poaceae, widely used as fodder and for straw supply on the direct sowing system at Rio Grande do Sul (RS). Ryegrass is a winter-culture weed, such as wheat, and it poses a problem during the initial phases of summer cultures, such as soy and corn.

Recebido para publicação em 29.1.2016 e aprovado em 1.3.2016.

2 Embrapa Trigo, Passo Fundo-RS, Brasil, <leandro.vargas@embrapa.br>; ${ }^{3}$ Universidade Federal de Pelotas, Pelotas-RS, Brasil; ${ }^{4}$ Embrapa Pecuária Sul, Bagé-RS, Brasil; ${ }^{5}$ Universidade Federal de Viçosa, Viçosa-MG, Brasil. 
Glyphosate is the main product used for vegetation management during the pre-sowing stage of the cultures. This herbicide acts by inhibiting the EPSPs enzyme, preventing the biosynthesis of aromatic amino acids phenylalanine, tyrosine and tryptophan, which are necessary for the synthesis of proteins. In the field, failures to control ryegrass with the use of glyphosate on areas infested with resistant biotypes have been observed.

Herbicide-resistant weeds may survive the application of products due to factors that may or may not be related to the site of action of the herbicide. When related to the site of action, resistance may be a result of the reduced affinity of the herbicide for the site of action (enzyme), as a result of DNA mutation, or due to the overexpression of this enzyme. Different EPSPs gene mutations have been reported for conferring resistance to glyphosate on Lolium rigidum (Kaundun et al., 2011), Lolium multiflorum (Perez-Jones et al., 2005) and Echinochloa colona (AlarcónReverte et al., 2013). When the resistance is not related to the site of action, it may occur due to mechanisms such as reduced absorption, reduced or increased translocation and increased metabolism and compartmentalization (Powles and Yu, 2010). Plant resistance caused by the metabolism of herbicide molecules is an important mechanism, since it is possible for a plant to become resistant to products with different mechanisms of action, even if they have never been used at a certain area (Powles and Yu, 2010). Metabolism-based resistance is a result of an increase on the metabolic detoxification rates of the herbicide.

The resistance caused by the increased metabolism may be studied using specific cytP450 inhibitors. The previous application of metabolism inhibitors may partially or completely reduce the expression of detoxifying enzymes, thus, reducing the resistance factor of the biotypes (Matzenbacher, 2012). The inhibition of the cyt-P450 complex by applying malathion and amitrol showed the multiple resistance to chlorsulfuron and diclofop, respectively, on a Lolium rigidum biotype, related to the metabolism of these herbicides (Yu et al., 2009).

Planta Daninha, Viçosa-MG, v. 34, n. 3, p. 565-573, 2016
Therefore, getting to know the mechanism through which ryegrass plants are becoming able to survive glyphosate on the crops of RS is important, since integrated management practices are determined based on this. For such, the objectives of this paper were: to quantify the accumulation of shikimic acid as a response to the glyphosate application; investigate the presence of mutations on the EPSPs gene; and evaluate the response to the application of glyphosate, after the treatment with the cyt-P450 monooxygenase metabolism inhibitor, for glyphosate susceptible and resistant biotypes.

\section{MATERIAL AND METHODS}

The seeds of the resistant ryegrass biotypes were collected from plants that survived the application of glyphosate on crops in the municipality of São Valentin, RS (SVA 1 and SVA 4), and Passo Fundo, RS (PFU 5), and the susceptible biotype seeds (SVA 2) were obtained in São Valentin, RS. Four ryegrass seeds were sown in pots with volumetric capacity for $4 \mathrm{~L}$; later on, when the plants had two leafs, thinning was conducted, leaving only one plant per pot. When there were six tillers, the plants were collected, and the tillers were separated; each tiller originated a new plant. The tillers were replanted on the Germina Plant ${ }^{\circledR}$ commercial substrate, and subjected to the application of glyphosate, at a dose of 2,160 g e.a. ha-1 (Glifosato Atanor $48^{\circledR}$ commercial product), 10 days after replanting, at which time they had 3-4 leafs. The application was conducted with a $\mathrm{CO}_{2}$ pressurized backpack sprayer with groundspray volume of $120 \mathrm{~L} \mathrm{ha}^{-1}$, equipped with 110.015 fan-type spraying nozzles.

The mother plants with surviving tillers were cut once again, offering material (clones) for the other experiments, and the tillers were transplanted to pots with volumetric capacity for $8 \mathrm{~L}$, containing red-yellow argisol and commercial substrate Germina Plant ${ }^{\circledR}$ at a 3:1 proportion. The specific materials and methods of each experiment are shown as follows.

\section{In vivo quantification bioassay for shikimic acid}

During the period from July to September 2013, two experiments were conducted, with 
an experimental design on completely randomized blocks with four repetitions. On the first experiment, in order to determine the best harvest time to quantify the shikimic acid, the treatments were arranged on a factorial scheme, whose factor A was constituted by ryegrass biotypes (SVA 1, SVA 2, SVA 4 and PFU 5), and factor B, by vegetal material collection times $(0,24,48,72$ and 96 hours after treatment - HAT. The plants were subject to glyphosate application during the tillering stage, at a dose of 2,160 g e.a. ha ${ }^{-1}$.

On the second experiment, the vegetal material was collected at the time indicated on the preliminary assay described, and it was taken to the laboratory for evaluation. The treatments were arranged on a factorial scheme, whose factor A tested the ryegrass biotypes (SVA 1, SVA 2, SVA 4 and PFU 5), and factor $\mathrm{B}$ was constituted by the application of increasing doses of glyphosate $(0,90,180,360$, 720, 1,440, 2,880; 5,760 and 11,520 g e.a. ha-1). The herbicide application conditions of both experiments were similar to the ones previously described.

The extraction of shikimic acid was conducted according to Singh and Shaner (1998), with changes made by Perez-Jones et al. (2007). The accumulation of this acid was measured using a spectrophotometer (Ultrospec $2000 \mathrm{UV} /$ Visible), with wavelength of $380 \mathrm{~nm}$. The shikimic acid concentration, expressed on $\mathrm{mg} \mathrm{mL}^{-1}$ of solution, was determined based on the standard curve with different known concentrations of shikimic acid $(0,20,40,60,80,100,120,140,160,180$ and $200 \mathrm{mg} \mathrm{mL}^{-1}$ ), diluted on HCL.

The obtained data were analyzed as to their normality using the Shapiro-Wilk test and, later on, they were subject to analysis of variance $(p \leq 0.05)$. In case of statistical significance, a regression analysis was conducted for the vegetal material collection time and glyphosate dose factors; for the biotype factor, the dose that offered $50 \%$ of shikimate accumulation was compared $\left(\mathrm{I}_{50}\right)$.

An analysis of regression was conducted, adjusting the data to the sigmoidal regression equations, according to Alarcón-Reverte et al. (2013):

$$
y=a /(1+\exp (-(x-x 0) / b))
$$

in which: $y=$ shikimate accumulation; $x=$ collection times or herbicide dose; and $a, x 0$ and $b=$ equation parameters, considering that $a$ is the difference between the maximum and minimum points of the curve; $x 0$ is the dose that offers $50 \%$ of response of the variable; and $b$ is the curve slope.

The values for $I_{50}$ were obtained through the arithmetic calculation of the necessary value to promote $50 \%$ of the response according to the parameters created on the curve equations. From the $I_{50}$ values, the factors of resistance (FR) were obtained for each biotype with suspected resistance, in comparison to the susceptible biotype. In order to use the FR, it was necessary to verify the reliability range $(p \geq 0.95)$ of the susceptible biotype in relation to the resistant biotype. Overlaying the reliability range of the susceptible biotype, in relation to the resistant biotype, indicates that there is no difference on the shikimate accumulation between the biotypes.

\section{EPSPs gene sequencing}

The total RNA was extracted from all ryegrass biotypes from $0.1 \mathrm{~g}$ of plant tissue, by biological repetition (three plants per biotype), using $500 \mu \mathrm{L}$ of the PureLink ${ }^{\mathrm{TM}}$ Plant RNA reactant (Invitrogen ${ }^{\mathrm{TM}}$ - USA), followed by a treatment with DNAse ${ }^{\mathrm{TM}}$ Amplification Grade (Invitrogen ${ }^{\mathrm{TM}}$ - USA) according to the instructions of the manufacturer. The quality and quantity of RNA were assured by an electrophoresis gel and spectrophotometry, respectively. cDNAs were obtained from $2 \mu \mathrm{g}$ of RNA, using the SuperScript ${ }^{\mathrm{TM}}$ III First-Strand Synthesis System for RT-PCR (Invitrogen ${ }^{\text {TM }}$ USA), according to the instructions of the manufacturer.

The polymerase chain reaction was conducted on a $100 \mu \mathrm{L}$ reactional mix, with $5 \mu \mathrm{L}$ of cDNA, $1 \mu \mathrm{M}$ of both forward $(\mathrm{F})$ and reverse (R) primers, $50 \mu \mathrm{L}$ of GoTaq ${ }^{\mathrm{TM}}$ Green Master Mix, 2x (Promega ${ }^{\mathrm{TM}}$ ) and nuclease-free water. The amplification was conducted on a thermocycler under the following conditions: initial denaturation at $94^{\circ} \mathrm{C}$ for $3 \mathrm{~min}$, 35 cycles of $94{ }^{\circ} \mathrm{C}$ for $60 \mathrm{~s}$, annealing of primers EPSPs_F (5'-CTGATGGCTGCTCCTTTAGCTC-3') 
and EPSPs_R (5'-CCCAGCTATCAGAATGC TCTGC-3') at $55^{\circ} \mathrm{C}$ for $60 \mathrm{~s}$, stretching at $72{ }^{\circ} \mathrm{C}$ for $60 \mathrm{~s}$ and final extension at $72{ }^{\circ} \mathrm{C}$ for $10 \mathrm{~min}$. The primers were obtained from a paper conducted by Salas et al. (2012), for the sequencing of the EPSPs gene on Lolium perenne spp. multiflorum.

The PCR products were purified using the PCR Purification Combo Kit (Invitrogen ${ }^{\mathrm{TM}}$ USA) and subject to a commercial sequencing service at the Ludwig Biotec laboratory, Alvorada - RS, using an ABI-PRISM 3100 Genetic Analyzer sequencer (Applied Biosystems). The gene sequences of the EPSPs enzyme obtained from all biotypes were analyzed as to the presence of the mutation responsible for the herbicide resistance; they were compared to each other using the Sequencer $5.1^{\circledR}$ program. In order to confirm the obtained sequences, they were previously compared to sequences from GenBank (www.ncbi.nlm.nih.gov/genbank).

\section{Study of the metabolism of the glyphosate herbicide}

An experiment was conducted from June to August 2013, on the greenhouse, with a completely randomized block experimental design with five repetitions. The treatments were arranged on a factorial scheme, whose factor A tested the ryegrass biotypes (SVA 1, SVA 2, SVA 4 and PFU 5), and factor B evaluated the inhibitors of cyt-P450 monooxigenase malathion and piperonyl butoxide (PBO), isolated or preceding glyphosate; isolated glyphosate; and control with no application.

The plants were subject to the application of the treatments when under the stage of four leafs to one tiller. Thirty minutes before applying the glyphosate herbicide, at a dose of 2,160 g e.a. ha ${ }^{-1}$, the metabolism inhibitors malathion (Malathion 500 EC Cheminova), at a dose of $1,000 \mathrm{~g}$ a.i. ha ${ }^{-1}$, and PBO, at a dose of 2,100 g a.i. ha ${ }^{-1}$ were applied. The conditions for the application of the herbicide and the inhibitors were similar to the ones previously described.

The analyzed variables were control at 21 and 28 DAT and the dry matter mass of the aerial part (MMSPA) at 28 DAT. The control evaluation was conducted using a percentage scale, in which zero $(0 \%)$ represented the absence of damages and one hundred (100\%), the death of the plants. In order to determine the MMSPA, the material was collected and then dried on a forced air circulation oven at $60{ }^{\circ} \mathrm{C}$ until a constant mass was obtained; at this point, the material was weighted and the value, transformed into the plant $\mathrm{MMSPA}^{-1}$.

The data was analyzed as to its normality using the Shapiro-Wilk test, and then the analysis of variance $(p \leq 0.05)$. When a statistical significance was observed, the Duncan test $(p \leq 0.05)$ was conducted for the biotype and inhibitor factors.

\section{RESULTS AND DISCUSSION}

The results and discussion of each experiment are described below, according to the sequence established on Materials and Methods.

\section{In vivo quantification bioassay for shikimic acid}

The best collection time to quantify the accumulation of shikimic acid was determined at 48 HAT with glyphosate (data not shown). An interaction was observed between the biotype and glyphosate herbicide dose factors for the shikimate accumulation variable, and the data was adjusted to the sigmoidal regression equation. The determination coefficient values $\left(R^{2}\right)$ varied from 0.91 to 0.97 , showing a satisfactory adjustment of the data to the model (Figure 1). From the equations, the $I_{50}$ values were calculated for the susceptible (SVA 2) and resistant (SVA 1, SVA 4 and PFU 5) ryegrass biotypes.

The application of glyphosate at a dose of 2,160 g e.a. ha-1 (corresponding to the maximal recommended dose on the product specifications) resulted on an accumulation of shikimic acid close to $10.41 \mathrm{mg} \mathrm{mL}^{-1}$ for the susceptible biotype, SVA 2, and this value is approximately 45,35 and $20 \%$ higher than the ones for the SVA 1, SVA 4 and PFU 5 biotypes, respectively (Figure 1). On Amaranthus palmeri, regardless of the glyphosate dose used, the shikimate accumulation on susceptible individuals was higher than on resistant 
individuals (Mohseni-Moghadam et al., 2013).

For the SVA 2 susceptible biotype, the dose of the glyphosate herbicide needed to accumulate $50 \%$ of shikimic acid was close to $190 \mathrm{~g}$ e.a. ha-1 (Figure 1 and Table 1). For the resistant biotypes SVA 1, SVA 4 and PFU 5, the necessary dose for $50 \%$ of shikimate accumulation was close to $1,130,1,200$ and 320 g e.a. ha ${ }^{-1}$, respectively (Figure 1 and Table 1). On a study with biotypes of Eleusine indica resistant to glyphosate in the state of Mississippi, shikimate accumulation values up to $800 \%$ higher than the ones of the susceptible biotype were observed (Molin et al., 2013).

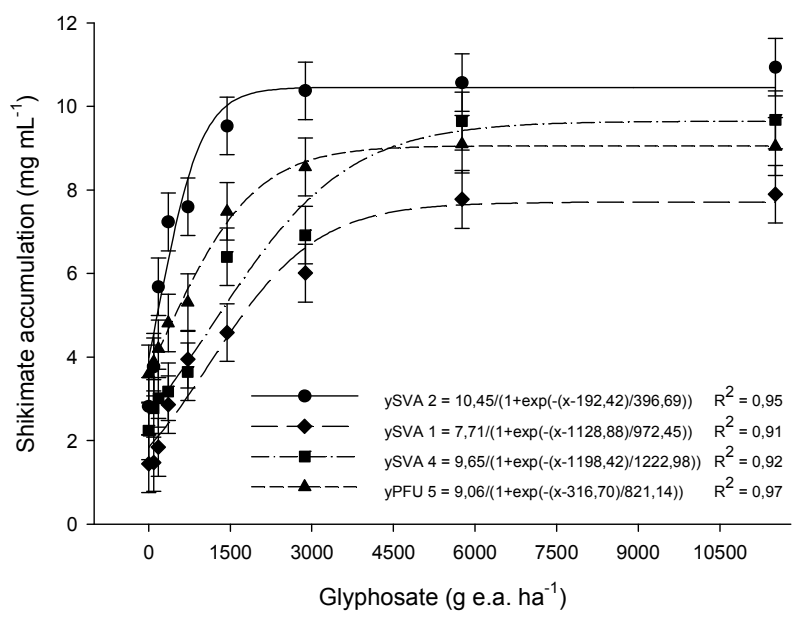

The points represent the mean values of the repetitions, and the bars, the respective reliability range of the mean.

Figure 1 - Shikimate accumulation $\left(\mathrm{mg} \mathrm{mL}^{-1}\right)$ of ryegrass biotypes (Lolium multiflorum) that are susceptible (SVA 2) and resistant (SVA 1, SVA 4 and PFU 5), due to the application of different doses of the glyphosate herbicide, evaluated 48 hours after treatment (HAT).

Based on the absence of an overlay of the reliability range (IC) of the susceptible biotype in relation to the IC of resistant biotypes (Figure 1 and Table 1), it was possible to establish the following values for the factor of resistance (FR): $5.9,6.2$ and 1.7 for SVA 1, SVA 4 and PFU 5, respectively, on the evaluation conducted at 48 HAT with glyphosate. In general, resistant Echinochloa colona plants accumulated less shikimic acid in comparison to the susceptible plants,
Table 1 - Necessary dose to accumulate $50 \%$ of shikimate $\left(\mathrm{I}_{50}\right)$, with reliability ranges (IC) and resistance factor of ryegrass biotypes (Lolium multiflorum) that are susceptible (SVA 2) and resistant (SVA 1, SVA 4 and PFU 5), in response to the application of different doses of the glyphosate herbicide, evaluated 48 hours after treatment (HAT)

\begin{tabular}{|l|c|c|c|}
\hline \multirow{2}{*}{ Biotype } & \multicolumn{2}{|c|}{$\mathrm{I}_{50}{ }^{1 /}$} & \multirow{2}{*}{$\begin{array}{c}\text { Resistance } \\
\text { Factor }^{2 /}\end{array}$} \\
\cline { 2 - 3 } & ${\text { g e.a. } \mathrm{ha}^{-1}}^{\prime}$ & $95 \%$ IC & - \\
\hline SVA 2 (S) & 192 & $159-226$ & - \\
\hline SVA 1 (R) & 1129 & $982-1276$ & $5.9^{*} \underline{-}$ \\
\hline SVA 4 (R) & 1198 & $1050-1346$ & $6.2^{*}$ \\
\hline PFU 5 (R) & 317 & $274-360$ & $1.7^{*}$ \\
\hline
\end{tabular}

1/ I50 = necessary dose to obtain $50 \%$ of shikimate accumulation. 2/ Resistance factor to the glyphosate herbicide by the Lolium multiflorum biotypes, obtained by dividing I50 of the resistant biotype (R) in relation to the susceptible biotype to the herbicide (S). ${ }^{3 /} *$ A significant different is indicated, characterized by the non-overlaying of the reliability range of I50 of the susceptible biotype in relation to the evaluated biotype.

using a wide range of concentrations of the glyphosate herbicide (Alarcón-Reverte et al., 2013). Based on the $I_{50}$ values obtained, the resistant plants were four times less susceptible to glyphosate, in comparison to the susceptible ones (Alarcon-Reverte et al., 2013). A study developed with crowfoot grass biotypes showed that the resistant biotypes showed FR values of 4.9, 6.2 and 8.0, calculated based on the shikimate accumulation (Molin et al., 2013).

The differential response to glyphosate observed between the biotypes refers to a resistance mechanism or mechanisms that mitigate the toxic effects resulting from the mechanism of action of glyphosate on plants (Alarcón-Reverte et al., 2013), and they may or may not be a result of the change on the site of action of the herbicide (Powles and Preston, 2006; Powles and Yu, 2010). The resistance mechanism due to the changed site of action may occur due to the exchange of one or more amino acids on the target enzyme, which hinders the correct coupling of the herbicide, or even due to the overexpression of the target enzyme (Powles and $\mathrm{Yu}, 2010)$.

On the other hand, when the resistance mechanism is not related to the change on the site of action, one or more factors act to hinder the herbicide to get to the inhibition 
point on lethal amounts, preventing its complete inhibition (Powles and $\mathrm{Yu}, 2010$ ). These mechanisms involve reduced absorption and/or translocation of herbicides, increased metabolism rates or the herbicide sequestration on metabolically inactive cellular organelles (Feng et al., 2004; PerezJones et al., 2007; Dinelli et al., 2008; Powles and $\mathrm{Yu}, 2010$ ).

Therefore, identifying and understanding the biochemical and physiological processes of the metabolism of plants, through which weeds develop resistance mechanism to herbicides, is important to offer a basis for the development of efficient strategies to manage the resistance to herbicides.

\section{EPSPs gene sequencing}

A $720 \mathrm{pb}$ region of the EPSPs gene was sequenced from the cDNA of susceptible (SVA 2) and resistant (SVA 1, SVA 4 and PFU 5) biotypes to the glyphosate herbicide. Although the entire ryegrass EPSPs gene has not been obtained, the sequenced region includes the domain in which the points of mutation are known to confer glyphosate resistance, for example, on position 106 of the proline amino acid (Pro).

The EPSPs partial sequence for resistant and susceptible ryegrass plants analyzed did not show any mutation at Pro $_{106}$ (Table 2) that has been associated with glyphosate resistance reported for the Lolium rigidum Gaudin (Kaundun et al., 2011) and Lolium multiflorum (Perez-Jones et al., 2005) species. However, the results found corroborate with those by Salas et al. (2012), which did not observe any mutation on the EPSPs gene on Lolium perenne biotypes.

Silent mutations were detected on position 103, of the alanine amino acid (Ala), from GCG to GCA on resistant biotypes SVA 4 and PFU 5, and also at Pro $_{106}$ from CCA to CCG on all analyzed biotypes, both resistant and susceptible ones, however, there was no resulting amino acid replacement (Table 2). On Lolium multiflorum biotypes that are susceptible to glyphosate, a silent mutation

Table 2 - Comparison of the partial sequences of the gene of 5-enolpyruvylshikimate-3-phosphate synthase (EPSPs) enzyme of the susceptible (SVA 2) and resistant (SVA 1, SVA 4 and PFU 5) Lolium multiflorum biotypes to the glyphosate herbicide and their corresponding sequence of amino acids

\begin{tabular}{|c|c|c|c|c|c|c|c|}
\hline $\begin{array}{l}\text { Amino acid (position): } \\
\text { Amino acid: } \\
\text { Nucleotide sequence: }\end{array}$ & $\begin{array}{c}103^{1 /} \\
\text { Ala } \\
\text { GCG }\end{array}$ & $\begin{array}{c}104 \\
\text { Met } \\
\text { ATG }\end{array}$ & $\begin{array}{c}105 \\
\text { Arg } \\
\text { CGG }\end{array}$ & $\begin{array}{c}106 \\
\text { Pro } \\
\text { CCA }\end{array}$ & $\begin{array}{c}107 \\
\text { Leu } \\
\text { TTG }\end{array}$ & $\begin{array}{c}108 \\
\text { Thr } \\
\text { ACG }\end{array}$ & $\begin{array}{c}109 \\
\text { Ala } \\
\text { GCD }^{-6}\end{array}$ \\
\hline Lolium rigidum $(\mathrm{S})^{\frac{2}{}}$ & --- & --- & --- & --- & --- & --- & GCA \\
\hline Lolium multiflorum $(\mathrm{S})^{\frac{3}{}}$ & $\mathrm{GCA}^{4 /}$ & $\begin{array}{ll}-- \\
\end{array}$ & --- & --- & --- & --- & GCT \\
\hline SVA 2 (S) & --- & --- & --- & $\mathrm{CCG}^{4 /}$ & --- & --- & GCG \\
\hline SVA 2 (S) & --- & --- & --- & --- & --- & --- & GCT \\
\hline Lolium rigidum $(\mathrm{R})^{2 /}$ & --- & --- & --- & $\mathrm{TCA}^{\frac{5}{}}$ Ser & --- & --- & GCA \\
\hline SVA $1(\mathrm{R})$ & --- & --- & --- & $\mathrm{CCG}^{4 /}$ & --- & --- & GCG \\
\hline SVA $1(\mathrm{R})$ & --- & --- & --- & --- & --- & --- & GCT \\
\hline SVA $1(\mathrm{R})$ & --- & --- & --- & $\mathrm{CCG}^{4 /}$ & --- & --- & GCG \\
\hline SVA 4 (R) & --- & --- & --- & $\mathrm{CCG}^{4 /}$ & --- & --- & GCG \\
\hline SVA $4(\mathrm{R})$ & --- & --- & --- & $\mathrm{CCG}^{4 /}$ & --- & --- & GCG \\
\hline SVA 4 (R) & $\mathrm{GCA}^{4 /}$ & --- & -- & --- & --- & --- & GCA \\
\hline PFU 5 (R) & --- & --- & --- & --- & --- & --- & GCT \\
\hline PFU 5 (R) & --- & --- & -- & $\mathrm{CCG}^{4 /}$ & --- & --- & GCG \\
\hline PFU 5 (R) & $\mathrm{GCA}^{4 /}$ & --- & -- & --- & --- & --- & GCA \\
\hline
\end{tabular}

1/ The amino acids were numbered based on the Arabidopsis thaliana sequence, adapted from Jasieniuk et al. (2008). ${ }^{2 /}$ Partial sequence of the gene of the EPSPs enzyme of susceptible (S) and resistant (R) Lolium rigidum to glyphosate (Simarmata and Penner, 2008). ${ }^{3} /$ Partial sequence of the gene of the EPSPs enzyme of susceptible (S) Lolium multiflorum to glyphosate (DQ153168.2). ${ }^{4 /}$ Silent mutation.

5/ Missense mutation; Ser $=$ abbreviation for Serine. ${ }^{6 / D}=\mathrm{A}, \mathrm{G}$ or T. 
was also found at $\mathrm{Ala}_{103}$ (Jasieniuk et al., 2008).

Variations on nucleotides (A, G or T) were also observed among resistant and susceptible individuals on the codon corresponding to position 109 of EPSPs, which codifies to the alanine amino acid (Table 2). These variations were also found on a paper conducted by Jasieniuk et al. (2008), on glyphosate resistant and susceptible Lolium multiflorum biotypes. The sequencing results provide evidence that the resistance to glyphosate reported by the studied populations has several origins.

Differences on the resistance mechanisms to glyphosate have been reported among the ryegrass populations and for several other species; however, the differences on the resistance mechanisms among plants within a population are rarely investigated (Salas et al., 2012). The lack of point mutations on the analyzed ryegrass biotypes suggests that another factor is contributing to the evolution of resistance on these populations.

\section{Study of the metabolism of glyphosate herbicide}

The Shapiro-Wilk test showed that data transformation is not necessary. An interaction of the factors was observed for all evaluation times and for the dry matter mass of the aerial part (MMSPA) (Table 3). The results found for control at 21 DAT (data not shown) were similar to the ones reported at 28 DAT.

The application of the isolated glyphosate herbicide at 28 DAT showed a control rate above $94 \%$ for the SVA 2 biotype; for the other biotypes, the control was lower (Table 3). The application of the isolated cyt-P450 inhibitors malathion and PBO showed no difference among the analyzed biotypes. On plants, in addition to the physiological functions for the synthesis of hormones, sterols and fatty acids and for several aspects of the secondary metabolism, the cyt-P450 enzymes are important for the detoxification of chemical substances, among which are the herbicides,

Table 3 - Control (\%) 28 days after the application of the treatments (DAT) and dry matter mass of the aerial part (g) of susceptible (SVA 2) and resistant (SVA 1, SVA 4 and PFU 5) ryegrass biotypes (Lolium multiflorum), subject to the application of glyphosate, isolated or thirty minutes after the application of the cyt-P450 monooxigenase inhibitors (malathion and PBO) and control with no application

\begin{tabular}{|c|c|c|c|c|}
\hline \multirow{2}{*}{ Treatment } & \multicolumn{4}{|c|}{ Biotype } \\
\hline & SVA $2(\mathrm{~S})^{1^{1 /}}$ & SVA $1(\mathrm{R})$ & SVA $4(\mathrm{R})$ & PFU $5(\mathrm{R})$ \\
\hline & \multicolumn{4}{|c|}{ Control (\%) at $28 \mathrm{DAT}^{2 /}$} \\
\hline Control & $0.0 \mathrm{a} \mathrm{B}$ & $0.0 \mathrm{a} \mathrm{B}$ & $0.0 \mathrm{a} \mathrm{C}$ & $0.0 \mathrm{a} \mathrm{D}$ \\
\hline Glyphosate & 99.8 a $\mathrm{A}$ & $3.5 \mathrm{c} \mathrm{A}$ & $3.8 \mathrm{c} \mathrm{A}$ & $6.8 \mathrm{~b} \mathrm{~B}$ \\
\hline Malathion & $0.0 \mathrm{a} \mathrm{B}$ & $0.0 \mathrm{a} \mathrm{B}$ & $0.0 \mathrm{a} \mathrm{C}$ & $0.0 \mathrm{a} \mathrm{D}$ \\
\hline PBO & $0.0 \mathrm{a} \mathrm{B}$ & $0.0 \mathrm{a} \mathrm{B}$ & $0.0 \mathrm{a} \mathrm{C}$ & $0.0 \mathrm{a} \mathrm{D}$ \\
\hline Glyphosate + Malathion & 99.6 a A & $4.0 \mathrm{~b} \mathrm{~A}$ & $2.5 \mathrm{c} \mathrm{B}$ & $3.2 \mathrm{bc} \mathrm{C}$ \\
\hline Glyphosate + PBO & $99.4 \mathrm{a} \mathrm{A}$ & $3.8 \mathrm{c} \mathrm{A}$ & $3.7 \mathrm{c} \mathrm{A}$ & $16.4 \mathrm{~b} \mathrm{~A}$ \\
\hline \multirow[t]{2}{*}{$\mathrm{CV}(\%)$} & \multicolumn{4}{|c|}{3.82} \\
\hline & \multicolumn{4}{|c|}{ Dry matter mass of the aerial part (g per plant) } \\
\hline Control & $2.0 \mathrm{bc} \mathrm{B}$ & $1.8 \mathrm{c} \mathrm{B}$ & $3.4 \mathrm{a} \mathrm{A}$ & $2.5 \mathrm{~b} \mathrm{~A}$ \\
\hline Glyphosate & $0.5 \mathrm{~b} \mathrm{C}$ & $1.4 \mathrm{a} \mathrm{C}$ & $1.8 \mathrm{a} \mathrm{D}$ & $1.6 \mathrm{a} \mathrm{C}$ \\
\hline Malathion & $2.0 \mathrm{~b} \mathrm{~B}$ & $2.3 \mathrm{~b} \mathrm{~A}$ & $3.3 \mathrm{a} \mathrm{A}$ & $2.2 \mathrm{~b} \mathrm{~B}$ \\
\hline PBO & $2.3 \mathrm{~b} \mathrm{~A}$ & $1.7 \mathrm{c} \mathrm{B}$ & $2.8 \mathrm{a} \mathrm{B}$ & $2.3 \mathrm{~b} \mathrm{AB}$ \\
\hline Glyphosate + Malathion & $0.5 \mathrm{c} \mathrm{C}$ & $1.3 \mathrm{~b} \mathrm{C}$ & $2.5 \mathrm{a} \mathrm{BC}$ & $1.4 \mathrm{~b} \mathrm{D}$ \\
\hline Glyphosate + PBO & $0.5 \mathrm{c} \mathrm{C}$ & $1.1 \mathrm{~b} \mathrm{C}$ & $2.3 \mathrm{a} \mathrm{C}$ & $1.1 \mathrm{~b} \mathrm{D}$ \\
\hline $\mathrm{CV}(\%)$ & \multicolumn{4}{|c|}{13.28} \\
\hline
\end{tabular}

${ }^{1 /}$ Susceptible (S) and resistant (R). ${ }^{2 /}$ Days after treatment. ${ }^{3 /}$ Means followed by the same letter, on the rows (lower case) and columns (upper case), are not significantly different according to Duncan's test ( $\mathrm{p} \leq 0.05)$. 
usually by hydroxylation or dealkylation (Powles and Yu, 2010).

Glyphosate + malathion showed a control rate above $90 \%$ at 28 DAT for SVA 2 (Table 3). The glyphosate + PBO treatment showed the control of the SVA 2 biotype close to $100 \%$ at 28 DAT. For the other biotypes, both treatments showed unsatisfactory control at the analyzed times. Applying the isolated herbicide, glyphosate + malathion and glyphosate + PBO showed no differences on the control for biotypes SVA 2 and SVA 1. For SVA 4, the isolated glyphosate and glyphosate + PBO showed higher performance in relation to the other treatments; however, para PFU 5, applying glyphosate + PBO showed higher control. The previous application of malathion and PBO did not offer increased control of gulf cockspur grass by quinclorac in relation to the one-time application of the herbicide to evaluate the control at $11,28,45,64$ and 100 DAT and the reduction of the dry mass of the aerial part at 38 DAT (Matzenbacher, 2012).

On the MMSPA variable, it was observed that the SVA 4 biotype was superior than the other biotypes in all analyzed treatments, except for the application of isolated glyphosate (Table 3). On the control treatment, a reduction of approximately 40,50 and $25 \%$ for the SVA 2, SVA 1 and PFU 5 biotypes, respectively, was observed in comparison with SVA 4. This biotype showed $1.8 \mathrm{~g}$ per plant of MMSPA when glyphosate was applied in isolation, and it was approximately $70 \%$ higher than the SVA 2 biotype. Malathion applied in isolation showed a reduction of $40 \%$ for SVA 2 , in comparison to SVA 4. When subject to the application of PBO, the SVA 4 biotype was $40 \%$ superior to the SVA 1biotype. The glyphosate + malathion and glyphosate + PBO treatments showed a decrease of approximately $80 \%$ of the SVA 2 biotype, in comparison to SVA 4 (Table 3).

Analyzing the MMSPA variable, it was observed that the application of $\mathrm{PBO}$ in isolation showed greater dry mass, in comparison to the other treatments, for the SVA 2 biotype (Table 3). For SVA 1, the use of malathion alone showed a better performance. A greater amount of dry matter mass was observed on the control and isolated malathion treatments with biotype
SVA 4, while for PFU 5, higher MMSPA was observed for the control, which was not statistically different than the treatment in which PBO was used alone.

The evaluated Lolium multiflorum biotypes showed no metabolic changes that would explain the mechanism of resistance to the glyphosate herbicide observed on crops in RS. The increased control and/or fresh matter mass of plants treated with the herbicide added to the inhibitor, in relation to plants treated only with the herbicide, suggests a possible involvement of the cyt-P450 or glutathione S-transferase enzymes on the metabolism of herbicides. Cyt-P450 is a large family of genes that perform an important role for the metabolism of several substances, acting on the oxidation of xenobiotics and promoting the detoxification of the organism (Zhu et al., 2008). Glyphosate-resistant soy plants expressed genes related to the action of cyt-P450 one, four and 24 hours after the application of the herbicide, and the expression was reduced in that period (Zhu et al., 2008).

Finally, the results of the paper showed that the susceptible SVA 2 biotype accumulated more shikimic acid than the resistant biotypes, regardless of the herbicide dose used. On the shikimic acid quantification bioassay, the resistant biotypes SVA 1, SVA 4 and PFU 5 showed resistance values of 5.9, 6.2 and 1.7, respectively, compared to the susceptible SVA 2 biotype. The EPSPs gene showed no mutation point previously associated to glyphosate resistance on the evaluated biotypes. The ryegrass biotypes showed no glyphosate metabolism by the cyt-P450 complex regarding the inhibition by malathion and $\mathrm{PBO}$.

\section{ACKNOWLEDGEMENTS}

To CNPq for their financial support Universal Notice MCT/CNPQ N 14/2012.

\section{LITERATURE CITED}

Alarcón-Reverte R. et al. Resistance to glyphosate in junglerice (Echinochloa colona) from California. Weed Sci. 2013;61:48-54.

Dinelli G. et al. Physiological and molecular basis of glyphosate resistance in Conyza bonariensis (L.) Cronq. biotypes from Spain. Weed Res. 2008;48:257-65. 
Feng P.C.C. et al. Investigations into glyphosate-resistant horseweed (Conyza canadensis): retention, uptake, translocation, and metabolism. Weed Sci. 2004;52:498-505.

Jasieniuk M. et al. Glyphosate-resistant italian ryegrass (Lolium multiflorum) in California: distribution, response to glyphosate, and molecular evidence for an altered target enzyme. Weed Sci. 2008;56:496-502.

Kaundun S.S. et al. A novel P106L mutation in EPSPS and an unknown mechanism(s) act additively to confer resistance to glyphosate in a South African Lolium rigidum population. J. Agric Food Chem. 2011;59:3227-33.

Matzenbacher F.O. Caracterização e controle de capimarroz (Echinochloa crus-galli) resistente aos herbicidas do grupo das imidazolinonas e quinclorac em arroz irrigado [dissertação]. Porto Alegre: Universidade Federal do Rio Grande do Sul, 2012.

Mohseni-Moghadam M., Schroeder J., Ashigh J. Mechanism of resistance and inheritance in glyphosate resistance palmer amaranth (Amaranthus palmeri) populations from New Mexico, USA. Weed Sci. 2013;61:517-25.

Molin W.T., Wright A.A., Nandula, V.K. Glyphosateresistant goosegrass from Mississippi. Agronomy.

2013;3:474-87.

Perez-Jones A. et al. Identification of glyphosate-resistant Italian ryegrass (Lolium multiflorum) in Oregon. Weed Sci. 2005;53:775-9.
Perez-Jones A. et al. Investigating the mechanisms of glyphosate resistance in Lolium multiflorum. Planta. 2007;226:395-404.

Powles S.B., Preston C. Evolved glyphosate resistance in plants: biochemical and genetic basis of resistance. Weed Technol. 2006;20:282-9.

Powles S.B., Yu Q. Evolution in action: plants resistant to herbicides. Ann Rev Plant Biol. 2010;61:317-47.

Salas R.A. et al. EPSPS gene amplification in glyphosateresistant Italian ryegrass (Lolium perenne ssp. multiflorum) from Arkansas. Pest Manage Sci. 2012;68:1223-30.

Simarmata M., Penner D. The basis for glyphosate resistance in rigid ryegrass (Lolium rigidum) from California. Weed Sci. 2008;56:181-88.

Singh B.K., Shaner D.L. Rapid determination of glyphosate injury to plants and identification of glyphosate-resistant plants. Weed Technol. 1998;12:527-30.

Yu Q. et al. Distinct non-target site mechanisms endow resistance to glyphosate, ACCase and ALS-inhibiting herbicides in multiple herbicide-resistant Lolium rigidum. Planta. 2009;230:713-23.

Zhu J.et al. Transcriptome response to glyphosate in sensitive and resistant soybean. J Agric Food Chem. 2008;56:6355-63. 